\title{
Integrating Technology into English Language Teaching in Nepal: Student and Teacher Perspectives
}

\author{
Yam Nath Adhikari \\ Department of English Education, Prithvi Narayan Campus, Pokhara, Nepal
}

\begin{abstract}
Article History: Submitted 14 February 2021; Reviewed 21 April 2021; Accepted 27 April 2021 Corresponding Author: Yam Nath Adhikari, Email: adhikariyamnath421@gmail.com DOI: https://doi.org/10.3126/paj.v4i0.37052

Copyright 2021 @ Author/s and Centre for Research and Innovation. This work is licensed under a Creative Commons Attribution 4.0 International (CC BY 4.0) License.
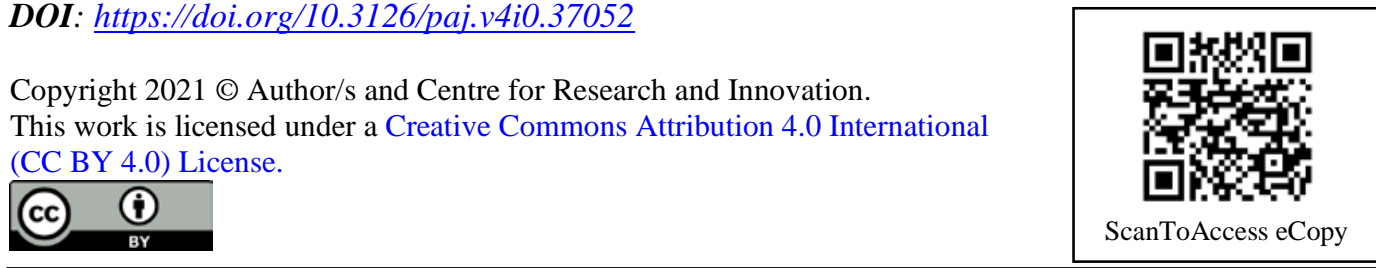

\begin{abstract}
Integrating technology into language teaching and learning is getting popularity in Nepal. Many educational institutions claim that they are adapting to technology in their curricular activities. This study aims to find out the secondary students' and teachers' perspectives on the integration of technology in English language teaching (ELT). As a qualitative research, it employs the semi-structured interview to investigate the participants' experiences of technology integrated language teaching in English as a Foreign Language (EFL) classroom. The findings of the study reported that technology integrated teaching promotes teachers' and students' performances, enriches studentcentred teaching strategies, develops learning opportunities and brings pedagogical changes. Technology also supports both teachers and students to be productive in language teaching. Technology integrated language teaching and learning advances coordination, cooperation, and collaboration among teachers and students. Various Information and Communication Technology (ICT) tools support both teachers and students to search and use different online materials relevant to their text. However, insufficient ICT infrastructures, poor bandwidth of internet and limited skill of ICT among teachers and students have become the obstacles to incorporate technology in the Nepali education system. To develop students' and teachers' skill of adapting to ICT in their language classroom, the concerned authority needs to provide a minimum ICT infrastructure to achieve the educational goals in Nepal.
\end{abstract}

KEYWORDS: ELT, ICT, internet, integration, pedagogy, videoconferencing

\section{INTRODUCTION}

In the modern era of ELT, media technology such as video, interactive games, use of the internet, chat rooms and videoconferencing have narrowed the distance and turned the whole world into a global community. Digital technology provides 
opportunities to learners to converse not only with the local community but with the global community as well, which has revolutionized learning and teaching methodologies, turning them more enjoyable and productive. Ahmad (2012) states that technology refers to computer-based interactive applications that use both hardware and software, allowing people to share their ideas and information among them. Integration of technology began in the 1950s, when small language schools began to use the phonograph, movies and the tape recorder as tools in English language teaching throughout the world. Golonka et al. (2014) argued that well-established technologies, such as personal computer and internet access, have become nearly ubiquitous for foreign language (FL) learning in many industrialized countries. Digital devices like computers, smartphones and tablets provide chances for learners to learn foreign language collaboratively in their own way. The use of digital technology in language teaching and learning is increasingly conjoint among students; teachers need to equip themselves with today's technology to make their lesson meaningful. Smartboards can be instrumental in engaging and motivating students in the classroom. For instance, though the teacher is not a native speaker, pronunciation can be taught to learners with ease using smartphone/board. Altun (2015) argues that the use of technology in English language teaching supports teachers to arouse the interest of the learners and technology has become an important part of the language learning process in and out of the classroom teaching and it helps to enrich their students to get a great deal of satisfaction.

Technology enables teachers to adopt modern pedagogy, thus enhancing the language learning process, the use of technology continues to develop the importance as a tool to help teachers in facilitating the language learning process for their learners. Today's language teachers need to learn how to take advantage of the technology and how to integrate it into their teaching skills to make their teaching and learning activities more interactive and meaningful. Ahmadi (2018) revealed that the integration of digital technology has assisted learners in improving their language learning skills. Borthwick and Brett (2014) showed that the effective use of new technologies improves learners' language learning skills. The innovation of the internet and collaborative tools and software offer new opportunities for educators in the delivery of content, in communication with their students and the wider world, for the creation and presentation of learning activities, and the management of course materials and assessments.

This study focused on using new technologies in teaching and learning English as a second/foreign language in Nepal. English is used as a foreign language in the context of Nepal. Pun (2013) stated that the spread and development of English around the world, has become an important means of communication among the people, the tradition of English language teaching has been drastically changed with the remarkable development of newer technologies and provides so many options as it encouraged teachers and students to make their teaching and learning collaborative, cooperative, supportive, interesting and productive. Chun et al. (2016) mentioned that technology enhances writing and gave new power to language not only by expanding the possibilities of human expression but also by providing a means for knowledge to be recorded and accumulated. Writing is the basis for much of our current-day electronic communication, and it is important to remember that it is as intrinsically bound to technological systems as it is to sign systems. The tools we use to write and read make a difference. Everyone brings its material properties, feel and techniques of use, affordances and limitations, and thereby establishes a particular relationship between writers or readers and texts.

Prithvi Academic Journal, Volume 4, May 2021 [pp. 107-120] 108 | P a g e 


\section{RESEARCH QUESTIONS}

The researcher sets the research questions and goes ahead to find the fact about the experiences of secondary teachers' and students' in integrating technology in the EFL classroom. The researcher tries to find out the ground reality about integrating technology in EFL teaching with the help of given research questions:

- What do secondary teachers and students experience in integrating technology in English language teaching and learning?

- How does technology help teachers and students in their teaching and learning English as a foreign language?

\section{REVIEW OF LITERATURE}

For this research article, I have reviewed theoretical literature based on three interrelated strands: the use of digital technology in the ELT classroom, pedagogical implications of ICT tools, and the role of technology and students' performance to practice in learning English language.

\section{Use of Digital Technology in the ELT Classroom}

The recent developments in information technology are taking language teaching in new directions and digital technology has become a part of modern pedagogy to adopt newer strategies in English language teaching. Son (2007) argued that the effective use of digital technology has been the main theme in language teaching circles and has focused in the computer-assisted language learning (CALL). The need of language teacher development in technology integration has become an important issue to address in various contexts of English language teaching and learning. Swockwell (2013) stated that technology has made it easier for teachers and learners of English to access a wide range of resources in terms of authentic input and communication with native and non-native speakers of English around the world. From the early days of CALL, technologies can play a role in motivating learners in language learning; as a result, technologies help to increase motivation of the learners towards foreign language learning. Many studies in the context of Nepal, Shields (2011), Dawadi and Shakya (2016), Rana et al. (2018), Laudari (2019) and Rana et al. (2019) stated that the incorporation of digital resources changed the instructional activities from a traditional to learner-friendly environment which supports both teachers and students to teach and learn in a meaningful situation. Kessler (2018) stated that language teachers today have many interesting options for using technology to enhance language learning procedure. To produce the technologically proficient manpower, it would be better to integrate technology in language teaching.

Technology integrated language teaching can be inspiring for those who are motivated to experiment with emerging technologies but lack of ICT skills among teachers can be challenging to identify which resources, tools, or Web sites may best fit a particular lesson, activity, or goal in the process of language teaching. Rana and Rana (2020) stated that it is good to train teachers not only in the technology but perhaps more significantly in innovative educational approaches. Thapa and Sein (2018) emphasised to reduce the gap, mass diffusion of the Internet and computers in the schools of developing countries has been promoted. There were good reasons behind this approach: Students get access to information sources; at the same time, they facilitate communication that can also stimulate the cooperation and collaboration in their learning among students and teachers over distance. Such a tendency has emphasised the essential role of technology in pedagogy in which technology has been dominant over teachers and students to make their teaching and learning activities productive. Most importantly, the new technologies 
have been discovered and disseminated so quickly that cannot avoid the attraction of teachers and learners, even both native and non-native speakers of English.

\section{Pedagogical Implications of ICT Tools}

Many language learners and teachers use CALL materials, which provide a range of language learning prospects to test and assess these tools and adapt them based on the aims and objectives of their teaching activities. Son (2018) stated that if their schools use a learning management system (LMS) such as Moodle for instance, they need to be familiar with basic functions of the LMS and be active in enabling language learning through the LMS and contributing to the customisation of the LMS to meet their educational objectives. Loveless (2011) found that using ICT as a 'tutor' draws upon learning ideas that support a range of learning experiences, from the practice of skills to developing conceptual understanding of both teachers and learners in the process of language teaching. Richards (2006) argued that effective integration of ICT in teaching and learning develops pedagogical as well as technological principles of interaction among teachers and students. The incorporation of ICT tools like YouTube and Google in academic activities promote the students' collaborative skills, which supports students to obtain a positive result in their learning. These ICT tools can also create a variety of opportunities for EFL students to practise English in and out of the classroom environment. Voogt et al. (2013) found that the notion of technology integration in a specific educational context benefits from a careful association of content, pedagogy and the potential of technology, and teachers who want to integrate technology in their teaching therefore need to be competent to make their teaching interactive, supportive, learners-friendly and meaningful. Lin and Zhang (2017) found that foreign-language teachers have both external and internal motivations to use technology in their classes and emphasized for technology integration in teacher education programs and such foreign language teacher-preparation programs provide opportunities for teachers to experience technology-enhanced teaching, with the aim of promoting their use of technology in their language teaching and learning.

ICT enables educational innovations by supporting teachers' and students' activities connecting them to each. The integration of technology in language teaching and learning appears to be an effective instructional technique to develop deeper understandings of the complex pedagogical process. The integration of ICT tools can certainly assist students in acquiring English Language competency as well as enhancing the quality of their learning experience. Samuel and Bakar (2006) emphasised that English lessons that incorporate multimedia applications can employ powerful motivation and provide bored students with exciting new ways to learn. English language teachers with the ICT integration have tried to determine the ICT skills of English language teachers in the light of existing infrastructure facilities to promote English language teaching and learning. Mertala (2017) found that to choose and use the right ICT tools at the right time, teachers must be prepared for learning about new tools, organizing in-class and out-of-class activities, guiding and monitoring students' engagement in online activities for evaluating students' learning performance. Pedagogical beliefs can be influenced positively based on the perceptions of learners towards different ICT devices and software in terms of their use in English language learning procedure.

\section{Technology and Students' Performance}

Technology can provide the complete tools and services for accessing any video and audio materials that are available in the public domain which helps students in their 
teaching and learning process. Abachi and Muhammad (2014) found that technology provides an access to the Wi-Fi networks, from which students can download different teaching materials and supports their learning but the speed of the connection depends on the number of users who simultaneously try to have access to the network. Besides, it improves security and easier access for communication purposes. Technology has assisted in raising learners' achievement and helps the learners to perform a very good job of engaging the learners in the material. Gilakjani (2017) argued that technology motivates students to take part in their educational tasks and helps to bring positive results in their learning performances from which students can get the chance to be familiar with the current trend of language learning happening in the world. In the context of Nepal, the majority of schools, teachers and students have faced difficulties to adopt technology in their curricular activities because of the poor bandwidth of the internet, unstable electricity supply and their economical background and the insufficient infrastructures of technology. Saglam and Sert (2012) found that limited skill of ICT among teachers and students inhibits the appropriate use of technology in teaching and learning. However, the initiation of different private and public schools and colleges assist the use of technology in Nepal. Lai and Tian (2016) argued that the integration of technology in English language teaching supports both teachers and students in achieving learning goals and processes equipping language learners with the pedagogical rationale for self-directed learning.

Students' perspectives in technology integrated ELT indicated that students perceive technology as positively contributory to their learning because it provides motivation, practicality, hands-on real-life learning experience. Timely and consistent teachers' feedbacks, opportunities to share learning outcomes and peer learning have created multiple learning styles. Technology created a sense of isolation among students because when technology is integrated into language teaching it leads to a pause in student-teacher interaction due to some pattern changes. In other words, it was suggested that teacher-to-student and student-to-student patterns disappeared because students were too busy with their laptops and responded neither to their peers nor to their teachers. Murray (2007) argued that the use of computer technology in English language teaching and learning, while no longer new, is still sufficiently new despite our primitive understanding of the value of technology, and of the extent to which it is readily available, especially in language learning contexts. So, it is significant to adapt to ICT in the language classroom to bring the verities in teaching and learning activities which arouse the interest of the learners towards the lesson.

\section{METHODOLOGY}

This paper adopts the interpretative research paradigm and obtains the qualitative data through semi-structured interviews with the participants (Cohen et al. 2013). Eight teachers and eight students of four secondary schools (two teachers and two students from each school) were purposively selected for their experiences in integrating technology in ELT and were approached through the personal contact for the interview. Students were determined by the referral of teachers to explore their experiences of integration of technology in ELT. After obtaining the informed consent from the participants, they were interviewed on multiple occasions up to data requirement. Interviews were recorded in my personal recording device and later stored in the laptop. Various archived documents were read before gathering data for interpreting the ground reality of the phenomenon and to ease on analysis of interviews.

Before collecting data, the participants were followed on their phone and Facebook Messenger which helped building a rapport with them. The interview records 
were transcribed, then organised thematically into the specific themes and interpreted using interpretive phenomenological analysis (IPA), based on Smith and Shinebourne (2012). The data gathered through interviews with teachers and students provided the ground reality in integration of technology in ELT in the secondary schools of Nepal. All the participants are renamed with pseudonyms to maintain anonymity.

\section{FINDINGS}

A cluster of findings from the overall study is reported here. These include findings related to the integration of technology in ELT in Nepal. The secondary school students and teachers' experiences enhance student-centred teachings and technology as a self-learning tool, and develop learning opportunities. Thus, technology is a source for pedagogical change in the process of language teaching in Nepal.

\section{Enhancement of Student-centered Teaching}

The majority of the participants in their interviews expressed that the integration of technology in ELT promotes the learner-friendly environment in the pedagogical process and develops the students' participation in classroom activities. In our interviews with students and teachers, they focused on the use of technology in language teaching to bring newness to the pedagogical process. The integration of technology in language teaching arouses the motivation towards the lesson and teachers express that their teaching becomes meaningful and supportive for both teachers and students. The participants in our interview appreciated the use of technology in the classroom, which develops the interaction among teachers and students in teaching and learning process. For example, Pralav a teacher at Pragati secondary school said:

Integration of technology in English language teaching has been a part of this time and it helps both teachers and students to make teaching-learning activities meaningful and lifelong.

The argument clearly indicated that how both teachers and students developed their knowledge of ICT tools and skills to organise and manage their teaching and learning activities effective with the integration of technology in their lesson. Particularly, teachers in our interviews put their views of using technology to enhance the learnerfriendly environment, which supports to develop the students' involvement in English language learning.

With the help of technology in a language classroom, teachers can show various teaching-learning materials through Google and YouTube which makes the language teaching interesting for both students and teachers. Priti a student from the same school shared her same kind of experience about the integration of technology in their language learning, for example,

Learning will be interesting and effective when they use technology in our classroom teaching. We can also have a chance of self-learning to know and understand our subject matter properly without the presence of our teachers. The tutorials on Google and YouTube also support us to understand the lesson effectively.

The expression reflected how both teachers and students developed their knowledge of ICT tools and skills to organise and manage their teaching and learning activities. Students in our interviews appreciated the integration of technology in English language teaching by their teachers where students can get an opportunity to develop self-learning by searching teaching and learning materials with or without the help of their teachers.

Jita, a student at Jyoti secondary school, shared her similar experiences of integration of technology in English language teaching, for example, 
Technology integrated language learning supports us to make our learning practical and it supports us to understand the lesson easily without any confusion. The use of internet-based materials in our English language learning helps us to avoid our confusions related to the texts.

It was clear that the integration of technology in language teaching assists the students' learning process and it makes students' learning long-lasting. The proper use of technology in teaching helps both teachers and students to search for supportive materials to make their lesson meaningful and interactive. Moreover, the participants in their interviews said that technology has been as the source materials to avoid confusions related to language teaching and learning for both teachers and students.

\section{Technology as a Self-Learning Tool}

The respondents involved in this study expressed that the integration of technology in language teaching is found as the self-learning tool in the sense that by using technology teachers and students can get an opportunity to update themselves to adopt the twenty-first century teaching and learning skills in this modern era of pedagogy. Students also search their learning materials integrating themselves with technology to make their learning practical. For example, Janak, a teacher at Jyoti secondary school, expressed his view,

Integration of technology in English language teaching provides opportunities in language learning both teachers and students can get the chance to share their feelings and experiences among teachers and students which helps to erase their difficulties and enhance their learning achievements.

The comment indicated that the use of technology in language teaching promotes both teachers' and students' cooperation, coordination and collaboration to develop a sense of self-learning strategy using various freely available ICT tools.

The integration of technology in English as a foreign language learning in Nepal supports all kinds of students and teachers to make teaching and learning easy by sharing their experiences among their friends and they help each other to use such technology to obtain higher learning achievements. For example, Sulav, a teacher at Shakti secondary school, shared his experience:

In my classroom teaching, I use audiovisual materials related to the texts using

ICT tools to make students easily understand the text and they become happy to watch such online videos and they take part in language learning. In such technology integrated language teaching, I found active participation of students in their learning.

The above comment provides a clearer picture of how the integration of technology helps teachers to make their teaching and learning activities effective, bringing technology into their classroom teaching. With the help of various ICT tools like Google and YouTube, teachers can bring a variety of language teaching to make their teaching meaningful and goal-oriented.

Students also took part in their language learning happily viewing to have newness in their learning while a language teacher integrates technology in his/her lesson. It provides a cooperative environment to learn different language skills sharing the experiences among the learners themselves. For instance, Kamal, a teacher at Kalyan secondary school, said:

I am a teacher and teaching English, for more than 20 years but nowadays technology makes teaching-learning activities meaningful and it supports to meet the objectives of the lesson. Students also get interested in language 
learning when I integrate technology in my lesson and students happily take part in the process of language learning.

It reflected that how the integration of technology in English as a foreign language classroom has assisted the learners to understand the text easily and the use of technology in teaching supports both teachers and students to be independent in their learning. It means that students can visit different sites to understand the text and they can involve themselves in their learning process with the help of the internet even in the absence of the teacher. Thus, the integration of technology saves time and provides an opportunity to update themselves with the current trend of English language learning and students are also found interested in language learning when teachers integrate technology in their language classroom.

\section{Development of Learning Opportunities}

The majority of the participants in our interview opine that the integration of technology in language teaching has been found as motivating and interesting in the classroom. It was found that the integration of technology in teaching makes teaching and learning activities more productive. The integration of technology in teaching and learning activities increases the motivation of students and also develops the students' participation in classroom activities. It has created better learning opportunities to develop learning performance of students as English language learners. For instance, Prapti, a teacher at Pragati secondary school, said:

In my opinion, the use of technology in language teaching is positive because it makes both teachers and students more productive in the sense that it saves their time and make students active in achieving the learning objectives by motiving them towards their learning.

The argument revealed that how the integration of technology develops teaching and learning performance of both teachers and students in English as a foreign language teaching in Nepal, it also helps meet the learning objectives in the classroom. Technology in the language classroom arouses the interest towards the lesson and students are found motivated in the language learning process. It also brings something newness while using technology in language teaching.

In addition, technology makes the students' learning meaningful interactive and productive. It is also being fruitful to decrease the teachers' talk time in the classroom and to make the learning achievement better. Kabita, a student at Kalyan secondary school, shares the similar type of experiences of using technology in English language learning as she says,

Integration of technology in language learning develops the students' motivation and participation towards language learning and supports to understand the text easily. Integration of technology in English language learning helps to develop the students' learning skills by interacting with our friends, seniors and teachers. It was clear from our interview that integrating technology in language teaching would be beneficial for many students who are not interactive because technology motivates EFL learners to take part in English language learning. They are also found supportive to each other in the process of language learning. Here is another student who expressed her opinion about the technology-friendly language class,

With the help of technology many students can have their open and distance learning in their free time and makes their learning easy. Students can get the opportunity of quality education from various part of the country if the schools are equipped with ICT. (Jagriti, a student from Jyoti Secondary School) 
It showed a clearer picture of how students can get a learning opportunity by using new technologies in English language teaching and learning and gradually take advantage of technology integrated language learning. Not only had that integration of technology also provided access to internet facilities that would promote distance and online learning. The integration of technology in English teaching gradually ensures opportunities for foreign language learners to achieve equal quality education even in remote areas of the country. Technology in education has found as a supportive tool to interact and develop learning opportunities of various learners from home and abroad to know the new ways of learning. In this way, students develop the students' collaborative skills in their independent learning.

\section{Technology as a Source for Pedagogical Change}

The interviews with the participants revealed that the integration of technology in English as a foreign language teaching has brought a change in the process of language teaching. Modern technologies have been the part of language teaching and learning to bring novelty in the pedagogical process, which has assisted both teachers and students to integrate them into the modern world of technology. With the advancement of technology, the field of teaching has shifted from the traditional mode of teaching to a learner-friendly mode. The integration of technology helps both teachers and students to adopt modern approaches to language teaching. For example, Janak, a teacher at Jyoti secondary school, said:

Integration of technology in English language teaching has brought some newness in teaching and learning strategy, with the help of technology in teaching increases the students' involvement in language teaching and teachers just play the role of facilitator to support the students' learning.

It was much clearer from his expression that the technology integrated language learning has found as a shift of pedagogy in this modern age where students and teachers can develop their self-learning with the help of technology. While integrating technology in language teaching, students and teachers realised that they learn a language in a meaningful environment. Both teachers and students can comfortably teach and learn the English language with fun, making their learning long-lasting for a better understanding.

The use of modern ICT tools in language teaching has created a favourable context for reforming and exploring language teaching in this new age. While a teacher integrates technology in his teaching, he or she is regarded as the competent teacher from the students' point of view and students themselves try to solve their difficulties in their learning. The majority of the participants involved in this study echoed that integration of technology has supported to transform of the traditional teacher talk method into a child-friendly strategy of teaching. For example, Bhim, a teacher at Bhawani Secondary School, said:

Previously we use just the chalk and talk method but nowadays we are being fascinated with newer ICT tools which have brought newness in the field of language teaching. By integrating technology we can update ourselves and our students and bring variety in language teaching.

The comment indicated that the incorporation of technology in language teaching has brought a change in the teaching and learning process. The majority of the participants in our interviews said that technology in language teaching has supported to bring newness in day to day teaching and learning activities. With the help of technology, teachers can adopt a new method of teaching and bring change in their pedagogical process from traditional method to child-centred method. 
The study also found that the integration of technology in teaching encouraged both teachers and students to be research-oriented to update their teaching-learning activities according to the need of the international market. With the advancement of technology, teachers and students become interested in it because they can achieve the goals of education even in a developing country like Nepal. So, it develops an interest in using technology among teachers and students to have better achievement in teaching and learning activities. However, some teachers in our interview argued that due to the lack of sufficient ICT infrastructures, public schools in Nepal are not getting opportunities to integrate technology in their teaching and learning process. For instance, Shuvam, a teacher at Shakti Secondary School expressed his view:

The schools are not technology-friendly and they are not equipped with technology. The school where I teach does not have access to laptop also. Very often I use my laptop to teach in the classroom.

The expression reflected that in the process of integrating technology many school teachers are facing problems of technology in classroom teaching because of the insufficient ICT tools. Teachers teaching English as a foreign language in the context of Nepal are unable to adopt ICT in their classroom teaching due to various problems related to technology. Many public schools in Nepal do not have access to ICT skilled manpower so teachers and students are facing problems though they would like to use technology in their classroom. So, to integrate technology in teaching and learning activities, schools need to be equipped with sufficient infrastructure of ICT.

\section{DISCUSSION}

The findings suggested that the popularity of integrating technology in ELT is expanding worldwide. Teachers of English expect the need of change in language teaching applying technology but the majority of them in Nepal still teach traditionally due to lack of ICT skills and are unable to adapt to technology effectively in their EFL classroom. However, this paper does not claim that none of these traditional manners is bad. The integration of technology in schools becomes essential through which students, teachers, policy-makers and institutions build modern and progressive identities (Rana et al. 2019), but in the absence of sufficient technology, the schools, teachers and students are unable to get benefits ef from the modern ICT for language teaching in Nepal. With regard to the use of utilities in the EFL classroom, in practice, a teacher can give tasks to students requiring them to work independently, in pairs, or in groups to find and present the information by integrating technology in the classroom, which resonates with the finding of Hicks (2011) that the integration of technology facilitates language teaching. Similar to the findings of the study, Golonka et al. (2014) reported that technology became an essential tool to develop the better achievement of teachers and students in their language classroom. The integration of technology in language teaching has provided opportunities for teachers and students to equip with innovative approaches in language teaching. In the context of Nepal, the integration of technology in teaching has supported the language teachers and students to achieve their learning objectives. It, to some extent, resonates with the findings of the studies Abachi and Muhammad (2014), Murray (2007), Saglam and Sert (2012) and Son (2018) that integrating technology in English language teaching helps to have interactive teaching activities to bring newness in the pedagogical process. This study reported that technology has been the source materials to address the confusions related to language teaching and learning for both teachers and students. This also resonates with the finding of Wang (2014) that integrating technology in education has found as a supportive tool to interact and develop learning opportunity of the various learners from home and abroad to update themselves 
with new ways of learning that promotes learning skills and enhance their knowledge in the field of education. This study found that the notion of technology integration in a specific educational context benefits to make teaching interactive, supportive, learnersfriendly and meaningful.

The effective integration of various ICT tools has brought the shift in pedagogy, which have supported the educational practitioners to bring variety in the field of teaching. This era of technology has promoted the values of interaction among teachers and students. However, the findings of the study somehow contrast with the earlier findings of the studies of Samuel and Bakar (2006), Chun et al. (2006), Lin and Zhang (2017) and Swockwell (2013) that lack of minimum ICT infrastructure, internet connectivity and students and teachers' knowledge of ICT, killed human resources and technology-integrated teaching and learning materials in the educational institutions that do not support teachers to integrate technology in language teaching in Nepal. Although The School Sector Development Plan 2016-2023 aims at equipping students with ICT skills, providing them with necessary learning materials, and improving the quality of education and management system (Ministry of Education, 2016). Besides, the findings of this study suggest that to bring newness and to shift the teacher-centred method to the learner-friendly method of language teaching teachers are needed to train them and ICT labs are required to develop in schools to promote their achievement in language learning.

As reported above, the findings indicated that an insufficient development of ICT resources has become a barrier in effectively integrating technology in language teaching in the context of Nepal. In the field of education, we faced the problem to bring all students and teachers in the reach of Videoconferencing teaching and learning activities during the COVID-19 crisis. This indicated that the concerned authority needs to be conscious of the possible danger that probably will happen in the future. So, it is required to develop minimum ICT infrastructures along with updating the teachers' skill and knowledge of ICT to integrate technology for a better pedagogical achievement.

\section{CONCLUSION}

The integration of technology in ELT has occupied an important space in English language teaching and learning. To make ELT activities interesting and productive, it would be better to integrate ICT in language teaching procedure. This study concluded that technology integration in EFL learning increases the learners' enthusiastic participation and develops the students' better academic performance. Hence, it turns the whole learning process as learner-centered. It is the teacher who gives proper guidelines as how to make the best use of media technology for acquiring language skills. With the help ICT tools, English as foreign/second language learners can get the chance of learning native English, incorporating technology in their language learning. After listening to native pattern of pronunciation, students found easier to pronounce the given words. They enjoyed the learning process while listening to native speakers. In this modern age, the use of media technology narrowed the distance of the world and the technological development has brought a new concept in the field of language teaching. The traditional approaches of language teaching have been replaced by the technology. The teacher-centered approach has shifted to learner-centered and teaching and learning activities has become productive when the new technology is integrated in each language teaching classroom. Students become research-oriented in their learning and search the text related online materials using the various freely available ICT tools like YouTube, Google and so on. The integration of newer technology in English language teaching in the Nepali educational institutions has 
supported students and teachers to adapt to newer strategies of teaching and has brought a positive change in their academic performance. However, the accessibility, affordability and lack of ICT skilled manpower are found as the greater problems among the teachers and students for their learning in the schools of Nepal. However, the initiation is found praiseworthy in the field of technology integrated education. A poor bandwidth of internet, limited technological skill of teachers and students and insufficient infrastructures of technology hinder the use ICT in ELT. To achieve the expected educational goal of Nepali education sector, it is needed to provide a minimum ICT infrastructure to all the schools of Nepal. Only then, we can increase access to education.

\section{REFERENCES}

Abachi, H. R., \& Muhammad, G. (2014). The impact of e-learning technology on students and educators. Computers in Human Behavior, 30, 491-496. https://doi.org/10.1016/j.chb.2013.06.018

Ahmad, J. (2012). English language teaching and integration of media technology. Procedia - Social and Behavioral Sciences, 47, 924-929. https://doi.org/10.1016/ j.sbspro.2012.06.758

Ahmadi, D. M. R. (2018). The use of technology in English language learning: A literature review [Research]. International Journal of Research in English Education, 3(2), 115-125. https://doi.org/10.29252/ijree.3.2.115

Altun, M. (2015). The integration of technology into foreign language teaching. International Journal on New Trends in Education, 6(1), 22-27.

Borthwick, K., \& Gallagher A. (2014). 'Inspiration, ideas, encouragement': Teacher development and improved use of technology in language teaching through open educational practice. Computer Assisted Language Learning, 27(2), 163-183. https://doi.org/10.1080/09588221.2013.818560

Chun, D., Kern, R., \& Smith, B. (2016). Technology in language use, language teaching, and language learning. The Modern Language Journal, 100(S1), 64-80. https://doi.org/10.1111/modl.12302

Cohen, L., Manion, L., \& Morrison, K. (2013). Research methods in education. Routledge.

Dawadi, B. R., \& Shakya, S. (2016). ICT implementation and infrastructure deployment approach for rural Nepal. In P. Meesad, S. Boonkrong, \& H. Unger (Eds.), Recent advances in information and communication technology 2016 (pp. 319331). Springer. https://doi.org/10.1007/978-3-319-40415-8_31

Gilakjani, A. P. (2017). A review of the literature on the integration of technology into the learning and teaching of English language skills. International Journal of English Linguistics, 7(5), 95-106. https://doi.org/doi:10.5539/ijel.v7n5p95

Golonka, E. M., Bowles, A. R., Frank, V. M., Richardson, D. L., \& Freynik, S. (2014). Technologies for foreign Language learning: A review of technology types and their effectiveness. Computer Assisted Language Learning, 27(1), 70-105. https://doi.org/10.1080/09588221.2012.700315

Hicks, S. D. (2011). Technology in today's classroom: Are you a tech-savvy teacher? The clearing house: A Journal of Educational Strategies, Issues and Ideas, 84(5), 188-191. https://doi.org/10.1080/00098655.2011.557406

Kessler, G. (2018). Technology and the future of language teaching. Foreign language annals, 51(1), 205-218. https://doi.org/10.1111/flan.12318

Lai, C., Shum, M., \& Tian, Y. (2016). Enhancing learners' self-directed use of technology for language learning: The effectiveness of an online training 
platform. Computer Assisted Language Learning, 29(1), 40-60. https://doi.org/10.1080/09588221.2014.889714

Laudari, S. (2019). Breaking barriers: Exploring digital practices of teacher educators in Nepal [Doctoral thesis, University of Technology Sydney]. Australia. http://hdl.handle.net/10453/137075

Liu, H., Lin, C. H., \& Zhang, D. (2017). Pedagogical beliefs and attitudes toward information and communication technology: A survey of teachers of English as a foreign language in China. Computer Assisted Language Learning, 30(8), 745765. https://doi.org/10.1080/09588221.2017.1347572

Loveless, A. (2011). Technology, pedagogy and education: Reflections on the accomplishment of what teachers know, do and believe in a digital age. Technology, Pedagogy and Education, 20(3), 301-316. https://doi.org/10.1080/ 1475939X.2011.610931

Mertala, P. (2017). Wag the dog- the nature and foundations of preschool educators' positive ICT pedagogical beliefs. computers in human behavior, 69, 197-206. https://doi.org/https://doi.org/10.1016/j.chb.2016.12.037

Ministry of Education. (2016). School sector development plan 2016-2023. Ministry of Education, Government of Nepal.

Murray, D. E. (2007). Creating a technology-rich English language learning environment. In International handbook of English language teaching (pp. 747762). Springer.

Pun, M. (2013). The use of multimedia technology in English language teaching: A global perspective. International Journal of Interdisciplinary Studies, 1(1), 2938. https://doi.org/https://doi.org/10.3126/ctbijis.v1i1.10466

Rana, K., Greenwood, J., \& Fox-Turnbull, W. (2019). Implementation of Nepal's education policy in ICT: Examining current practice through an ecological model. The Electronic Journal of Information Systems in Developing Countries, 86(2), e12118. https://doi.org/10.1002/isd2.12118

Rana, K., Greenwood, J., Fox-Turnbull, W., \& Wise, S. (2018). A Shift from traditional pedagogy in Nepali rural primary schools? Rural teachers' capacity to reflect ICT policy in their practice. International Journal of Education and Development using ICT, 14(3).

Rana, K., \& Rana, K. (2020). ICT integration in teaching and learning activities in higher education: A case study of Nepal's teacher education. Online Journal of Educational Technology, 8(1), 36-47. https://doi.org/10.17220/mojet. 2020.01 .003

Richards, C. (2006). Towards an integrated framework for designing effective ICT-supported learning environments: The challenge to better link technology and pedagogy. Technology, Pedagogy and Education, 15(2), 239-255. https://doi.org/10.1080/14759390600769771

Saglam, A. L. G., \& Sert, S. (2012). Perceptions of in-service teachers regarding technology integrated english language teaching. Online Submission, 3(3), 1-14.

Samuel, R., \& Bakar, Z. (2006). The utilization and integration of ICT tools in promoting english language teaching and learning: Reflections from English option teachers in Kuala Langat District, Malaysia. International Journal of Education Development Using ICT, 2(2), 4-14.

Shields, R. (2011). ICT or I see tea? Modernity, technology and education in Nepal. Globalisation, Societies and Education, 9(1), 85-97. https://doi.org/10.1080/ 14767724.2010.513536 
Smith, J. A., \& Shinebourne, P. (2012). Interpretative phenomenological analysis. In H. Cooper, P. M. Camic, D. L. Long, A. T. Panter, D. Rindskopf, \& K. J. Sher (Eds.), APA handbook of research methods in Psychology: Research designs: Quantitative, qualitative, neuropsychological, and biological (Vol. 2, pp. 73-82). American Psychological Association. https://doi.org/10.1037/13620-005

Son, J.B. (2007). Technology and language teacher education. In Teacher Development in Technology-Enhanced Language Teaching (pp. 3-28). Palgrave Macmillan, Cham. https://doi.org/10.1007/978-3-319-75711-7_1

Stockwell, G. (2013). Technology and motivation in English-language teaching and learning. In International perspectives on motivation (pp. 156-175). Springer

Thapa, D., \& Sein, M. K. (2018). An ecological model of bridging the digital divide in education: A case study of OLPC deployment in Nepal. The Electronic Journal of Information Systems in Developing Countries, 84(2), e12018. https://doi.org/10.1002/isd2.12018

Voogt, J., Fisser, P., Pareja Roblin, N., iTondeur, J., \& van Braak, J. (2013). Technological pedagogical content knowledge - A review of the literature. Journal of Computer Assisted Learning, 29(2), 109-121. https://doi.org/10.1111/ j.1365-2729.2012.00487.x

Wang, M. J. Y. (2014). The current practice of integration of information communication technology to English teaching and the emotions involved in Blended learning. Turkish Online Journal of Educational Technology, 13(3), 188-201. 